\title{
Lung Metastasis of Murine Melanomas Is Mediated by a Lung-Specific Endothelial Cell Adhesion Molecule
}

\author{
肺への特異的な腫瘍の転移は肺内皮細胞上の分子 \\ Lu-ECAM-1を腫瘍が見分けるためである
}

Zhu, D., Cheng, C.F., and Pauli, B.U. Proc. Natl. Acad. Sci. USA (1991) 88, $9568-9572$

Key Words: endothelial cell adhesion molecule, lung specific metastasis, Lu-ECAM-1

Mechanisms of organ-specific adhesion of tumor cells during metastatis have eluded investigators for a long time. Lung metastatic B16 F10 and RAW $117 \mathrm{~L} 17$ tumor cells adhere specifically to monolayers of lung-derived endothelial cells. Similar phenomenon has been observed in brain-metastatic glioma cells, liver metastatic RAW 117H10, and MRGA lymphoma cells. Previously, Pauli and Lee[Lab. Invest. (1988) 58, 379-387] have provided an elegant in vitro assay to determine the nature of the adhesion molecule present in the extracellular matrix of endothelial cells by measuring their phenotypic expression when tumor cells are in contact with them.

In the present study, Pauli et al. have purified a lung specific endothelial cell adhesion molecule(Lu-ECAM-1) by immunoaffinity chromatography using monoclonal antibody mAb6D3, generated against cell surface determinants of lung matrix-modulated BAECs(bovine aorta endothelial cells) and selection of a $\mathrm{mAb}$ by inhibition of the binding of lung specific metastatic B16 melanoma cells to lung matrix-modulated BAECs. Lu-ECAM-1, a $90 \mathrm{kDa}$ glycoprotein, is expressed by endothelial of distinct lung vascular branches and is not observed in vessels of other tissues as determined by ELISA assay using mAb6D3. The expression of Lu-ECAM-1 is not regulated by other cytokines such as tumor necrosis factor $\alpha$, lipopolysaccharides, recombinant interleukin-1- $\alpha$ and phorbol myristate acetate. Such is not the case for other adhesion molecules like ELAM-1, ICAM-1, and INCAM110.

The present investigators have measured the inhibition of lung colonization by anti Lu-ECAM-1 mAb in a very elegant manner. mAb6D3 was tested for its efficiency to inhibit the formation of lung metastatis in a colony assay. Synergenic mice were injected with mAb 6D3 and one hour later with tumor cells. The number of colonies was counted in experimental and control animals 21 days later. A significant reduction in the number of lung colonies was observed in anti-LuECAM-1 mAb 6D3 treated mice. The specificity of LuECAM-1 was further strengthed by immunolocalization. Murine homologous mouse Lu-ECAM-1 expression on endothelial of lung vascular bed correlated well with the topographical dis-
腫瘍が転移する時に器官特異的な転移が起こるメカニズム は、精力的な研究が為されてきたにも拘らず、仲々分からな かった。肺に転移を起こすB16F10及びRAW117L17腫瘍細胞 は、肺由来内皮の単層培養細胞上に特異的に接着する。同様な 現象は脳に転移を起こす神経膠腫細胞、肝臓転移性の RAW117H10やMRGAリンパ腫細胞で知られている。PauliとLee は、腫瘍細胞を加えた時に内皮細胞に接着することを見るとい うやり方で、内皮細胞上の接着分子の性質を調べるという大変 エレガントなin vitroのアッセイ系を開発している[Lab. Invest. (1988) 58, 379-387]。

ここで紹介する論文でPauliらは、肺マトリックスで変調し た BAEC(ウシ大動脈内皮細胞)細胞表層上の決定基に対して単ク ローン抗体を作成し、その中から肺に特異的な転移を起こす B16メラノーマ細胞がこのBAECに接着することを妨げる単ク ローン抗体を選んだ。その中の単クローン抗体6D3を用い免疫 アフィニティクロマトグラフィーをすることで、肺特異的内皮 細胞接着分子(Lu-ECAM-1)を精製した。Lu-ECAM-1は90 kDaの 糖タンパク質で、単クローン抗体6D3を用いたELISA法による と、肺の毛細血管の内皮細胞上には発現されているが、他の組 織の血管内皮には見つからなかった。ELAM-1、ICAM-1、

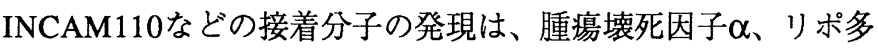

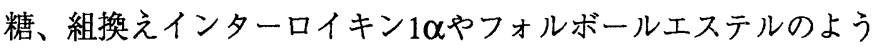
なサイトカインにより調節されているが、Lu-ECAM-1はこれら により影響を受けない。

この論文の著者達は、抗-Lu-ECAM-1単クローン抗体によ る肺への転移阻止を、非常に巧みに示している。コロニー形成 アッセイにより単クローン抗体6D3が肺への転移成立を妨げる 効率を調べている。この時、同系マウスに6D3を注入してから1 時間後に腫瘍細胞を尾静脈から注入した。21日後に調べると、 対象群に較べて、単クローン抗体6D3をあらかじめ注射した肺 コロニーマウスでは、形成率が90\%以上抑えられていた。LuECAM-1の局在性を抗体を用いて調べると、B16メラノーマ細胞 
tribution of experimental B16 lung metastasis. mAb6D3 stained more prominently in vascular regions.

More than $90 \%$ reduction of the experimental metastates in animals pretreated with anti-Lu-ECAM-1 mAb6D3 relative to control mice suggests that $\mathrm{Lu}-\mathrm{ECAM}-1$ is the principle endothelial cell adhesion molecule for lung metastatic melanoma cells. Although quite speculative, this may be a lead for development of anti-adhesion therapy for prevention of cancer metastases.

The modulation of the metastasis process by the organspecific adhesion molecules located on the luminal surface of the endothelial cells may be similar to the process of pre-T cell homing. If this is the case, it will be of interest to investigate adhesion molecules related to the homing of pre-T cells.

\section{Reported by Shridhar P. Damle}

Laboratory of Glycoconjugate Research Mitsubishi Kasei Institute of Life Sciences

Tokyo 194, Japan
の肺への転移時の局在性と、肺の毛細血管内皮でのLu-ECAM-1 の発現はよく一致していた。

以上のことから、Lu-ECAM-1は肺へ転移するメラノーマ細 胞に対する主要な内皮細胞接着因子であると思われる。まだ確 実とは言えないが、これが癌の転移を防ぐ接着阻止療法を開発 する糸口となるかも知れない。

内皮細胞上に存在する器官特異的接着分子による転移過程 の調節は、T前駆細胞が胸腺にたどり着く過程に似ているかも 知れない。もしそうなら、T前駆細胞のホーミングに関与した 接着分子をこのような手法で調べれば大変面白いだろう。

三菱化成生命科学研究所 · 複合糖質研究室

シュリダハールP.ダムレ

三菱化成生命科学研究所 · 複合糖質研究室

山形 達也訳

\section{Please Cite Minireviews and Other Articles of TIGG in Your Paper!}

As you may have seen from the cummulative contents of Trends in Glycoscience and Glycotechnology, published in Vol. 4(No. 15) 138141(1992), this journal contains a lot of useful information. Please cite "Trends Glycosci. Glycotechnol.", when you write your papers or present your data in meetings. Citation data for Trends Glycosci. Glycotechnol. are very important for the future growth of this journal. Please do not forget that TIGG is your own journal.

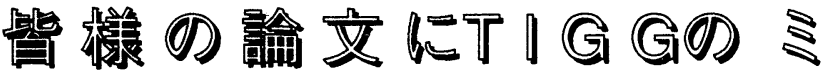

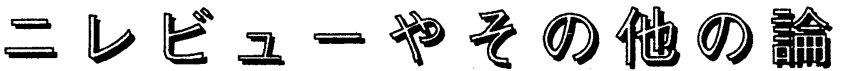

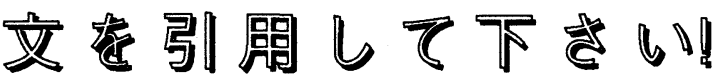
既に御存知かと思いますが、Trends in Gycoscience and Glycotechnology, Vol. 4(No. 15) 138-141に印刷されている総目次にありま すように、この雑誌は有益な情報で一杯で す。皆様が論文を書かれる時、また学会等で 発表される時は、どうかTrends Glycosci.Glycotechnol.を引用して下さい。引用のデータは Trends Glycosci. Glycotechnol.のこれからの発 展に大変重要なのです。どうかTIGGは皆様 自身の雑誌である事をお忘れにならないよう お願い申し上げます。 